\title{
STRUCTURES, ENDOWMENTS, AND INSTITUTIONS IN THE ECONOMIC HISTORY OF LATIN AMERICA
}

\author{
John H. Coatsworth \\ Harvard University
}

The economic history of Latin America has become more voluminous, complex, and fascinating in the past decade. ${ }^{1}$ The new work has already provoked noteworthy commentaries; one could even write an historiography of the historiography. ${ }^{2}$ The purpose of this essay is to comment on (and applaud) the re-emergence of political economy in the economic history of the region. By this I mean the renewal of interest in the Big Questions that inspired the structuralists, "cepalinos," Marxists, dependentistas, and modernizationists of the post-World War II generations. Economic historians are again worrying about the long, long run, about the connections between social stratification, political power, and economic strategy, and about the relative impact of structures, endowments, and institutions on economic growth and development.

This essay first reviews what economic historians take as their key dependent variables, that is, the productivity of economies and the welfare of the people who make them work. We know much more now than we did only a decade or so ago about the evolution of gross domestic product (GDP) per capita and changes in living standards over the past several centuries. Second, it touches on the subject that Joseph Love addresses at greater length in his contribution to this issue, namely, the rise

1. Four collections of varying scope provide a representative sample: Stephen Haber, ed., How Latin America Fell Behind: Essays on the Economic Histories of Brazil and Mexico, 1800-1914 (Stanford: Stanford University Press, 1997); John H. Coatsworth and Alan M. Taylor, eds., Latin America and the World Economy Since 1800 (Cambridge: Harvard University Press, 1998); Rosemary Thorp, ed., An Economic History of Twentieth-Century Latin America, 3 vols. (New York: Oxford University Press, 2000); and Victor Bulmer-Thomas, John H. Coatsworth, and Roberto Cortés Conde, eds., The Cambridge Economic History of Latin America (New York: Cambridge University Press, forthcoming 2006).

2. On this topic, see Paul Gootenberg's penetrating review essay in a recent issue of this journal: "Between a Rock and a Softer Place: Reflections on Some Recent Economic History of Latin America," LARR 39, no. 2 (June 2004): 239-57.

Latin American Research Review, Vol. 40, No. 3, October 2005

(C) 2005 by the University of Texas Press, P.O. Box 7819, Austin, TX 78713-7819 
and fall of structuralism and related macrohistorical approaches to understanding the determinants of Latin America's relative economic backwardness. Third, it takes a look at some of the most interesting recent efforts to restart discussion and debate on the same macro-level issues that preoccupied the structuralists and their offshoots and critics. Finally, as is customary, the concluding section brews up a stew of unanswered questions, well-intentioned speculation, and gratuitous advice.

Over the past decade or so, new efforts to estimate long-term trends in productivity and welfare have managed to refine our knowledge of Latin America's economic history in ways that now make it possible to ask old questions with greater precision, and even to raise altogether new questions. Productivity is generally measured as GDP per capita. Though reliable data are still lacking, and GDP estimates for the nineteenth century and earlier will always contain substantial margins of error, the independent guesswork of many scholars is converging towards consensus on some, though not all, of the main trends over the past three centuries.

The most ambitious effort to produce estimates of GDP per capita that are comparable across time and between countries and regions is that of Angus Maddison, who began publishing historical estimates of GDP per capita for all world regions in the late $1980 \mathrm{~s} .{ }^{3} \mathrm{He}$ has continued to adjust and refine his efforts up to at least 2003. ${ }^{4}$ Maddison's estimates, which go back as far as the year $1 \mathrm{AD}$, are calculated in constant "international dollars" of 1990. By converting all his estimates to the same currency units and adjusting them to eliminate the effects of differences in price levels, Maddison aimed at providing PPP ("purchasing power parity") estimates that can then be compared across time and space. Though his figures are useful as indicators, the pre-twentieth-century estimates are admittedly quite rough, and not always well documented or explained. ${ }^{5}$

Despite methodological differences and continuing debates over particular cases, however, the Maddison estimates appear to embody an

3. See Angus Maddison, "Explaining the Economic Performance of Nations," in Convergence of Productivity: Cross-National Studies and Historical Evidence, ed. William Baumol, Richard Nelson, and Edward Wolff (Oxford: Oxford University Press, 1994), $20-61$.

4. Angus Maddison, The World Economy: Historical Statistics (Paris: OECD, 2003), 11350. A number of the historical estimates of GDP and GDP per capita in this source differ from estimates Maddison published earlier.

5. Maddison's figures for Mexico, for example, include GDP per capita estimates for 1820, 1850, 1870, and 1877. His estimates are based on figures published by Mexico's Instituto Nacional de Estadística, Geografía e Informática (INEGI) in 1985 for 1800, 1845, 1860, and 1877, which Maddison extrapolated between these dates to produce estimates for the years he needed. INEGI's estimates were actually taken from those I published 
emerging consensus on long term trends (see table 1). It is now generally accepted that the areas of Latin America under effective Spanish or Portuguese control probably enjoyed per capita incomes on a par with Western Europe and at least equal to the British colonies that became the United States well into the eighteenth century. Maddison, for example, estimates that in 1700 the thirteen British colonies in North America had a per capita GDP well below the Caribbean and Mexico and barely equal to the average for Latin America. Others have put Cuba's GDP per capita higher than that of the United States until the 1830s, though Mexico had already fallen well behind by $1800 .{ }^{6}$ It also seems well established that during the half century after the outbreak of the independence wars in 1810, little if any economic growth occurred in most of Latin America. The pampas region of Argentina (cattle hides and wool) and copper-rich Chile probably began growing earlier than Brazil and the other former Spanish colonies; Mexican GDP per capita actually fell substantially after $1810 .^{7}$

The larger Latin American economies and many smaller ones began to achieve sustained increases in GDP per capita starting at some point in the late nineteenth or early twentieth century. Since 1870, according to Maddison, the eight major economies of Latin America have grown at a rate roughly equal to that of the United States overall, though faster before 1930 than afterwards. In fact, until World War II, the big eight economies grew faster than the average of all the advanced countries that later formed the Organisation for Economic Co-operation and Development (OECD). Convergence ended with the era of import-substitution

in 1978, which INEGI converted from 1970 dollars to pesos at the 1970 rate of exchange of 26.5 pesos to the dollar. Maddison divided each of INEGI's figures by exactly 2.5 to convert them from 1970 pesos to 1990 dollars. Maddison's Mexican estimates are found in Maddison, The World Economy, 191. The original estimates were published in John H. Coatsworth, "Obstacles to Economic Growth in Nineteenth-Century Mexico," American Historical Review 83, no. 1 (February 1978): 82; the INEGI figures, which cite this source are in Estadísticas históricas de México, 2 vols (Mexico, 1985), 1:300, 311 (table 9.1).

6. For Cuba, see Pedro Fraile Balbín, Richard J. Salvucci, and Linda K. Salvucci, "El caso cubano: Exportación e independencia" in La independencia americana: Consecuencias económicas, ed. Leandro Prados de la Escosura and Samuel Amaral (Madrid: Alianza Universidad, 1993), part II, chap. 3. See also John H. Coatsworth, "Economic and Institutional Trajectories in Nineteenth-Century Latin America," in Latin America and the World Economy Since 1800, edited with Alan M. Taylor (Cambridge: Harvard University Press, 1998), 23-54.

7. Anecdotal evidence suggests that Mexican GDP per capita fell sharply during the independence wars. Partial recoveries occurred in brief periods and certain regions. See, for example, Margaret Chowning's useful study of Michoacán that argues for a recovery in agriculture (the sector least affected by Mexico's turmoil) from the late 1830s to 1845 in Wealth and Power in Provincial Mexico: Michoacán from the Late Colony to the Revolution (Stanford, CA: Stanford University Press, 1999). However, there is no credible evidence in the literature to suggest that GDP per capita for the country as a whole returned to late colonial levels until the early Porfiriato. 
Table 1 GDP Per Capita (In International Dollars of 1990)

\begin{tabular}{|c|c|c|c|c|c|c|c|}
\hline & 1500 & 1600 & 1700 & 1820 & 1870 & 1900 & 2000 \\
\hline \multicolumn{8}{|l|}{ Mexico } \\
\hline (Maddison) & 425 & 454 & 568 & 759 & 674 & 1,366 & 7,218 \\
\hline $\begin{array}{l}\text { Mexico } \\
\text { (Coatsworth) }\end{array}$ & c. 550 & 755 & 755 & 566 & 642 & 1,435 & \\
\hline $\begin{array}{l}\text { Other Latin America } \\
\text { (excluding } \\
\text { the Caribbean) }\end{array}$ & 410 & 431 & 502 & 663 & 683 & & 5,508 \\
\hline Brazil & 400 & 428 & 459 & 646 & 713 & 678 & 5,556 \\
\hline Caribbean countries & 400 & 430 & 650 & 636 & 549 & 880 & 5,634 \\
\hline Latin America & 416 & 438 & 527 & 692 & 681 & 1,110 & 5,838 \\
\hline USA & 400 & 400 & 527 & 1,231 & 2,445 & 4,091 & 28,129 \\
\hline
\end{tabular}

industrialization (ISI). Inward-oriented growth strategies worked better in some places than others, but did poorly overall. Unfortunately, the collapse of ISI has not yet produced a successful alternative. In the last quarter of the twentieth century, Latin American per capita GDP growth fell to half that of the United States (0.91 percent per year for Latin America versus 1.86 for the United States in 1973-2001). ${ }^{8}$

Data on living standards show similar trends: Stagnation until the late nineteenth century and slow but steady improvement thereafter. In most of Latin America, for example, life expectancy at birth (30-35 years) and infant mortality rates (near 300 per 1000 live births) stood at levels comparable to the Roman empire until 1900 or so; literacy rates in most countries had not yet reached 30 percent of the adult population. ${ }^{9}$ Over the course of the twentieth century, life expectancy has risen to more than 70 years and infant mortality has fallen by an order of magnitude,

8. Maddison, The World Economy, 263. See also the discussion in the editors' "Introduction" to Gerardo Della Paolera and Alan M. Taylor, eds., A New Economic History of Argentina (Cambridge, UK: Cambridge University Press, 2003), 1-18. The experience of individual countries varied, of course. Argentina reaped spectacular gains up to 1913 and grew more slowly than the rest of Latin America after 1930. Mexico's productivity gains of the pre-1930 era were interrupted by the revolution of 1910, but the Mexican economy grew faster than most during the ISI era.

9. The Mexican case is representative. See INEGI, Estadísticas históricas de México, 2 vols. (Mexico: INEGI, 1985). Countries and regions of predominantly European settlement with 
to 30 or less per 1000 in most countries. New work on the height of populations going back to the pre-Hispanic era has begun to shed light on fluctuations in the biological standard of living. ${ }^{10}$ While differences are apparent across regions and time periods, sustained improvements are largely a twentieth-century phenomenon. This pattern differs from that of earlier industrializations in Britain, the United States, and Western Europe where productivity rose rapidly during the nineteenthcentury industrial revolution while living standards fell or stagnated and did not catch up until decades later. ${ }^{11}$ In Latin America, productivity and welfare indicators rose together in the twentieth century.

Though living standards rose, inequality also increased. Modernization appears to have produced a massive new concentration of land ownership provoked, inter alia, by railroads that brought opportunities for commercial exploitation to once isolated regions; technological change (especially in sugar) that created economies of scale; the rapid development of large banana plantations in the tropics; and the sale of public lands in large blocks to land and survey companies and well-connected entrepreneurs. ${ }^{12}$ The new concentration of land ownership provoked violence in the densely populated indigenous provinces of central and

smaller populations of indigenous or African descent tended to raise literacy and achieve improvements in health indicators more rapidly than others. For literacy rates, see Elisa Mariscal and Kenneth L. Sokoloff, "Schooling, Suffrage, and the Persistence of Inequality in the Americas, 1800-1945," in Political Institutions and Economic Growth in Latin America, ed. Stephen Haber (Stanford: Hoover Institution Press, 2000), 165-75.

10. For an excellent recent example of this work, which makes use of an unusually large data set, see Adolfo Meisel R. and Margarita Vega A., "La estatura de los colombianos: Un ensayo de antropometría histórica, 1910-2002 (Documentos de Trabajo sobre Economía Regional 45, Centro de Estudios Regionales, Banco de la República, Cartagena, May 2004). See also Moramay López Alonso and Raúl Porras Condey, "The Ups and Downs of Mexican Economic Growth: The Biological Standard of Living and Inequality, 1870-1950," Economics and Human Biology 1 (2003): 169-86. The Mexican data show a decline in heights from the 1870s to the 1920s with improvements thereafter.

11. On living standards during industrial revolutions, see John Komlos, "Shrinking in a Growing Economy: The Mystery of Physical Stature during the Industrial Revolution," Journal of Economic History 58, no. 3 (September 1998): 779-802, and Roderick Floud and Richard Steckel, eds., Health and Welfare during Industrialization (Chicago: University of Chicago Press, 1997).

12. On the impact of railroads on landownership in Mexico, see John H. Coatsworth, "Railroads, Landholding and Agrarian Protest in the Early Porfiriato," Hispanic American Historical Review 54, no. 1 (February 1974): 48-71. For the Cuban case, and an interesting reinterpretation of the consequences of concentration in sugar, see Alan Dye, Cuban Sugar in the Age of Mass Production: Technology and the Economics of the Sugar Central, 1899-1929 (Stanford: Stanford University Press, 1998); on the vast size of banana plantations, see the classic work by Charles Morrow Wilson, Empire in Green and Gold: The Story of the American Banana Trade (New York: H. Holt and Co., 1947). On the surveys and sales of public lands, see Robert H. Holden, Mexico and the Survey of Public Lands: The Management of Modernization (DeKalb, IL: Northern Illinois University Press, 1994). 
southern Mexico and later in parts of the Andean highlands. ${ }^{13}$ In Argentina, land ownership tended toward concentration much earlier, as the government rewarded friends and Indian fighters with vast tracts starting soon after independence and lasting through the "Conquest of the Desert" in 1879. The effect of these giveaways on the concentration of wealth and income was limited, however, because land values stayed low until railroads and refrigerator ships created opportunities for profitable commercial exploitation on a large scale. ${ }^{14}$ The trend toward concentration of wealth in the countryside coincided in many countries with rising rewards for owners of capital, land, and skills relative to the wages of unskilled majorities. Immigration from southern Europe to Argentina, Brazil, Uruguay and elsewhere tended to increase the downward pressure on wages. ${ }^{15}$ Unlike other modernizing regions, most of Latin America did not experience a reverse trend toward great equality later in the development process. In the post-World War II era, two powerful trends worked against equality. First, the reigning model of state-led import-substitution industrialization tended to increase wage inequality both by inflating wages in protected industries and by providing relatively high salaries and benefits to state employees. Second, the Cold War political and economic alliance that the dominant classes and governing elites of Latin America forged with the United States gave Latin America a half century of governments decidedly more conservative on social issues than most of the region's population.

High levels of inequality had at least two important consequences for most Latin American countries. First, inequality slowed improvements in living standards. Latin American welfare indicators did improve over the course of the twentieth century, but inequality compounded by high population growth rates made progress slower

13. For an attempt at quantification, see John H. Coatsworth, "Patterns of Rural Rebellion in Latin America: Mexico in Comparative Perspective," in Riot, Rebellion, and Revolution: Rural Social Conflict in Mexico, ed. Friedrich Katz (Princeton: Princeton University Press, 1988), 21-62.

14. On Argentina, see the essay by Tulio Halperin Donghi, "Argentina: Liberalism in a Country Born Liberal," in Guiding the Invisible Hand: Economic Liberalism and the State in Latin American History, ed. Joseph L. Love and Nils Jacobsen (New York: Praeger, 1988), 99-116. See also, Lyman Johnson, "The Frontier as an Arena of Social and Economic Change: Wealth Distribution in Nineteenth-Century Buenos Aires Province" (Unpub. paper, n.d.).

15. In Argentina, real wages actually rose over this period, but Alan M. Taylor argues that without immigration, wages would have been 25 percent higher on the eve of World War I in "Peopling the Pampas: On the Impact of Mass Migration to the River Plate, 1870-1914," Explorations in Economic History 34, no. 1 (1997): 100-23; see also Jeffrey G. Williamson, "Winners and Losers over Two Centuries of Globalization" (National Bureau of Economic Research, Working paper 9161 Cambridge, MA: September 2002), 1723. 
than elsewhere. Second, inequality contributed to keeping poverty rates exceptionally high throughout much of the region into the twenty-first century. Latin America remains today the most unequal region in the world. ${ }^{16}$

Much of what we know now about these historical trends, particularly in quantitative terms, is knowledge that originated in research that began in the 1950s. Moreover, the issues raised by the postwar generation of structuralist economists, and their dependentista offspring in the 1960s and 1970s, have now returned to enrich, if sometimes also to frustrate, scholarly debate at the dawn of this new century. As Love demonstrates, the intellectual history of economic debate in the post-World War II era left a vast and varied landscape of great peaks and valleys, and not a few swampy areas ready to trap the unwary traveler. We now know three important things about the structuralists, including particularly the cepalinos (those who worked for, or more broadly those who were trained by or generally agreed with CEPAL, the UN Economic Commission for Latin America) that have not received adequate attention in the historiography. The first is that, in addition to their theoretical work and their essays in general economic history, the cepalinos created and implemented ambitious programs of economic research and data collection in one country after another. In several countries, the first serious efforts to construct national accounts and develop plausible estimates of past trends in GDP were carried out by CEPAL or by CEPALtrained economists. ${ }^{17}$ It is simply untrue that the structuralists and dependentistas did not do serious quantitative or qualitative empirical research; often, they were the first economic historians to do so. ${ }^{18}$

16. For a survey of the twentieth century, see Rosemary Thorp, Progress, Poverty and Exclusion: An Economic History of Latin America in the Twentieth Century (Baltimore: Johns Hopkins University Press, 1998), chap. 13.

17. On Chile for example, see United Nations Economic Commission for Latin America (ECLA or in Spanish CEPAL), Antecedentes sobre el desarrollo económico de la economía chilena 1925-52 (Santiago, Chile: Pacífico, 1954); see also the two volumes on Argentina published in 1959 as part of the larger project of the entitled Análisis y proyecciones del desarrollo económico, Part V. El desarrollo económico de la Argentina, 2 vols. (Mexico: United Nations Department of Economic and Social Affairs, 1959).

18. Inexplicably, Stephen Haber's introductory chapter to How Latin America Fell Behind (cited above) suggests that structuralists and dependentistas were guilty of neglect and even contempt for empirical research. In this case, it was Haber who got the facts wrong. Even more sweeping, and anachronistic, was Douglass C. North's identification of "Latin American studies" with "a long tradition ... [of] dependency explanations of the region's lagged growth" and the bizarre suggestion that integrating "history, economics, and politics ... has not been part of . . the literature on Latin American development ..." in North, "Concluding Remarks: The Emerging New Economic History of Latin America," in Haber, ed., Political Institutions and Economic Growth in Latin America, 273. 
Second, we now know, too, that CEPAL's endorsement of importsubstitution industrialization based on high levels of tariff protection had been the dominant economic policy strategy in every major Latin American economy for at least the preceding half century. Indeed, Latin America was the most protectionist region in the entire world for as far back as the data go, that is, the mid-nineteenth century. Mexico, Argentina, Brazil, Peru, and Chile all adopted explicit policies of industrial protection well before World War I. In the 1930s, when conventional accounts suggest that the region turned inward, Latin America actually lost its position as the most protectionist region in the world, as other regions adopted high tariff strategies and caught up. What changed in Latin America in the 1930s, but then only slowly, was the use of nontariff barriers to complement the high tariff regimes that had already been in place for a century-and the beginnings of state-led industrial promotion in addition to protection. ${ }^{19}$

Third, we now also know that the United States supported, promoted and pressured for the adoption of ISI policies throughout the less-developed world in the 1950s. It is true that the United States opposed the creation of CEPAL and did its best to discredit the agency and its advice, but the U.S. objections to CEPAL had nothing to do with ISI per se. They focused on CEPAL's advocacy of state planning and regulation. The United States feared that CEPAL-influenced economic policies would lead to the creation of state enterprises or subsidies to domestic companies, either of which would close off opportunities for U.S. multinational businesses that were seeking to jump over tariff walls and build branch plants producing for domestic markets in the larger Latin American countries. ${ }^{20}$

The key link between the structuralists and the later dependency school writers-apart from the fact that they were often the same people-was the preoccupation of both with institutions as key determinants of economic success or failure. For Raúl Prebisch, the key to understanding the alleged deterioration in terms of trade, which he thought affected most of Latin America and the developing world, lay not in the market place but in the institutional arena. Terms of trade deteriorated for primary product producers because union contracts in the manufacturing industries of the developed world made it difficult to lower wages during recessions and oligopolistic industries effectively colluded to reduce production rather than lower prices when demand

19. See John H. Coatsworth and Jeffrey G. Williamson, "Always Protectionist? Latin American Tariffs from Independence to Great Depression," Journal of Latin American Studies 36, no. 2 (May 2004): 205-32.

20. Sylvia Maxfield and James Nolt, "Protectionism and the Internationalization of Capital: U.S. Sponsorship of Import Substitution Industrialization in the Philippines, Turkey and Argentina," International Studies Quarterly 34 (1990): 44-81. 


\section{Latin American Research Review}

fell. ${ }^{21}$ The absence of such effective private institutions in the third world made it impossible to pursue a similar strategy there. Within Latin America, as Love points out, the structuralists focused on institutional "structures," such as the concentration of land ownership. One of the most important debates erupted over the structuralist claim that latifundismo caused inflation by limiting the supply of agricultural products. The Chicago School economists effectively rebutted this argument by showing inflation stemmed not from inelastic supplies of agricultural (or other) products but from an oversupply of money linked to government deficits. ${ }^{22}$

The generation of dependency school writers of the 1960s and 1970s is conventionally assumed to have been interested primarily in the economic relations between the developed core of capitalist industrial nations and the underdeveloped periphery. Actually, most of the dependentistas, such as Fernando Henrique Cardoso and Enzo Falleto to take the iconic case, devoted almost no time at all to analyzing Latin America's relations with the developed world. ${ }^{23}$ Instead, they focused attention on the impact of trends in the external sector (including export production and foreign direct capital investment) on the evolution of domestic class formation, economic structure, political coalitions and institutions. Much of what they discovered and wrote about on these issues is now accepted as commonplace and uncontroversial. Much less durable were the dependentista models that focused directly on external economic relationships. Prebisch's hypothesis on the terms of trade was probably wrong, though still debated..$^{24}$ Models of "unequal exchange" or surplus extraction and transfer from the periphery to the core could not be verified empirically. ${ }^{25}$

21. See United Nations Economic Commission for Latin America, The Economic Development of Latin America and its Principal Problems (Lake Success, N.Y.: CEPAL, 1950); see also Joseph Love's essay in this issue.

22. See Love's discussion of the structuralists in this issue. For a clear expression of the view, now universally accepted, that money supply determines the rate of inflation in any structural environment, see Arnold Harberger, "El problema de la inflación en América Latina," Boletín Mensual of the Centro de Estudios Monetarios (Buenos Aires, Argentina), June 1966: 253-69.

23. Fernando Henrique Cardoso and Enzo Faletto, Dependency and Development in Latin America (Berkeley: University of California Press, 1979).

24. On the terms of trade debate, see Christopher Blatman, Jason Hwang, and Jeffrey G. Williamson, "The Terms of Trade and Economic Growth in the Periphery, 1870-1983" (Working Paper 9940 National Bureau of Economic Research, Cambridge, MA, August 2003).

25. See for example, the late Andre Gunder Frank's influential Capitalism and Underdevelopment in Latin America: Historical Studies of Chile and Brazil (New York: Monthly Review Press, 1967); less well known outside Latin America was the work of Ruy Mauro Marini, Dialéctica de la dependencia (Mexico: Ediciones Era, 1973). 
Most important of all, the consensus among economists and economic historians of Latin America on the relationship between external ties and economic performance has now shifted 180 degrees from half a century ago. The structuralist and dependentista generations believed that Latin America's external economic ties to the developed world would promote economic growth only if carefully regulated by a powerful state. Many, like Celso Furtado, argued that past episodes of export booms had depleted soils or extracted minerals and ended with "involutions," economic downturns that left entire regions and economies worse off than before. Most believed that vigorous state intervention could manipulate external trade and capital flows to promote domestic industry and escape this historic pattern, but some writers were more pessimistic. ${ }^{26}$ Economic historical research in the past two decades, some of it based on empirical work initiated by the dependentistas themselves, has now produced a contrary consensus: In the long run, countries open to external trade and capital flows have tended to grow faster and reach higher levels of GDP per capita sooner than others. This is true for as far back as the late colonial era. ${ }^{27}$

Since the structuralist and dependentista scholars apparently got the growth issue wrong, succeeding scholars have tended to overlook what they got right. Three of the key insights in this literature are now reemerging, so it is particularly relevant to point them out. First, the dependentistas insisted that the less-developed world could not succeed economically by following the path trod by the developed nations. To some extent, this insistence arose as a response to the equally insistent modernizationist view that the Anglo-American model, understood as demonstrating the efficacy of open markets and free trade, should be adopted by Latin America. The counter-argument was all too easy to make: Latin America was different, and faced a different international environment in the late twentieth century than Britain and the United States did in the early nineteenth century.

Second, they claimed, accurately it appears, that external dependence exacerbated economic inequality in the less-developed world. Fernando Henrique Cardoso argued, for example, that external dependence did not make economic growth impossible, but merely immoral.$^{28}$ Of course, long before the onset of export-led economic growth, the subjugation of

26. See the lucid discussion of Furtado in Love's essay in this issue.

27. See Coatsworth, "Trajectories." For an econometric test for the twentieth century, see Alan M. Taylor, "On the Costs of Inward-Looking Development: Price Distortions, Growth, and Divergence in Latin America," The Journal of Economic History 58, no. 1. (March 1998): 1-28.

28. See Fernando Henrique Cardoso, "Industrialization, Dependency and Power in Latin America," Berkeley Journal of Sociology 17 (1972): 79-95. 


\section{Latin American Research Review}

Native Americans and the enslavement and forced migration of Africans had already embedded inequality in the fabric of many Latin American societies. The relative weight to be given to the historic inequality in legal status and class structure associated with caste and slave systems, as opposed to the inequality in income and wealth exacerbated by onset of modernization is still being debated (see below). Third, the structuralist and dependentista emphasis on issues of political economy and institutional development also has a newly contemporary ring. Few of the cepalinos then or now would be surprised to learn that economic historians, along with economists and political scientists, are now tending to the view that inequality leads to the creation of institutions that inhibit economic performance.

The military regimes that closed off political debate throughout Latin America between 1963 and the 1980s left a permanent mark on the intellectual history of the region. Some of the military regimes (for example, in Argentina and Brazil) espoused a kind of primitive nationalism that proved to be consistent with structuralist and dependentista arguments about the need for state-led management of both the domestic economy and external economic relations. Few followed the Chilean regime's decision to embrace open markets and free trade. Though an odd scatter of dependentistas turned up working for such military rulers, the main effect of military rule was to put an end to grand theories as well as utopian visions. It was not just that these regimes overtly stigmatized and punished such thinking; more profound was the widespread belief that such theories and visions had failed.

In economic history, the turn from macrohistorical questions to microeconomic issues coincided with this general trend. The coincidence was obscured by the persistence of competition between the still controversial "neoclassical" approach to economics and older institutionalist and Marxist traditions. The arrival in Latin America of the "New Economic History," which first swept the United States in the 1960s, was probably delayed both by local resistance and by the relative decline in academic research on Latin America in the United States that occurred in the 1970s and 1980s. These caveats aside, the focus of the new economic historians on questions derived mainly from microeconomic theory was consistent with trends in other disciplines. Moreover, the emergence of the Washington Consensus ${ }^{29}$ and the collapse of socialism in Eastern Europe contributed to the view that, even if history had not

29. The term "Washington Consensus" was coined by John Williamson in a volume of papers he edited entitled Latin American Adjustment: How Much Has Happened? (Washington, D.C.: Institute for International Economics, 1990). The Washington Consensus in Williamson's definition included better fiscal management, deregulation of product, factor, and currency markets, privatization of public assets, and more effective governance. 
quite ended, most of the Big Questions had now been settled. The research of this era looked at the impact of technological change (especially railroads), ${ }^{30}$ industrial and business history, ${ }^{31}$ and the design of policies and institutions in key sectors of the region's larger economies. ${ }^{32}$ This work contributed significantly to the economic historiography of Latin America. It also makes it possible to return to the Big Questions with a much more solid empirical and analytical foundation.

In the twenty-five years of the Washington Consensus, the Latin American economies have experienced their worst quarter century since the catastrophic second quarter of the nineteenth century. Initially, the collapse of growth rates was attributed to the effects of the financial crisis precipitated by the Mexican devaluation and de facto default in August 1982. By the mid-1980s, however, most of the region had begun abandoning the failed ISI strategies of the previous half century and was embracing market-friendly reforms, including greater openness to external trade and investment. While growth rates did recover somewhat in the 1990s, they fell again in the recession that greeted the twentyfirst century. In a number of cases, growth remained anemic or proved short-lived despite major economic policy reforms. The empirical evidence linking growth rates to Washington Consensus structural reforms is weak (except for openness to trade, which is associated with faster growth). ${ }^{33}$ Economists have generally argued, nonetheless, that a major determinant of the crises and difficulties in the 1990s and early 2000s was failure to implement the reforms fully, especially those related to fiscal restraint. ${ }^{34}$ Most also take the view that while economic reforms may constitute a necessary condition for success, they are not sufficient

30. John H. Coatsworth, Growth Against Development: The Economic Impact of Railroads in Porfirian Mexico (DeKalb: Northern Illinois University Press, 1981); William R. Summerhill, Order Against Progress: Government, Foreign Investment, and Railroads in Brazil, 1854-1913 (Stanford: Stanford University Press, 2003).

31. See, for example, Richard J. Salvucci, Textiles and Capitalism in Mexico: An Economic History of the Obrajes, 1539-1840 (Princeton, N.J.: Princeton University Press, 1987); Stephen Haber, Industrialization and Underdevelopment (Stanford: Stanford University Press, 1989).

32. See, for example, Stephen Haber, "The Efficiency Consequences of Institutional Change: Financial Market Regulation and Productivity Growth in Brazil, 1866-1934," in Latin America and the World Economy Since 1800, ed. John H. Coatsworth and Alan M. Taylor (Cambridge, MA: Harvard University Press, 1996), 275-322.

33. Eduardo Lora and Ugo Panizza, "Structural Reforms in Latin America Under Scrutiny" (Research Department Working paper Washington, DC, Inter-American Development Bank, 2002).

34. See, for example, Arminio Fraga's balanced summary in "Latin America Since the 1990s: Rising from the Sickbed," Journal of Economic Perspectives 18, no. 2 (Spring 2004): 1-18. 
to guarantee faster growth. Some have pointed to geographic obstacles to economic growth, ${ }^{35}$ but in recent years discussions have focused increasingly on institutional deficiencies-inadequate protection of property rights, inefficient and corrupt bureaucracies and courts, and multiple public sector failures evidenced by widespread tax evasion, procurement fraud, crumbling infrastructure, inadequate regulatory systems, lagging education and health services, and the like. ${ }^{36}$

Institutions have histories. Most institutional histories contain two key elements: politics and path dependence. Institutions are created and sustained by private groups and public entities in the political arena. They tend to come in mutually reinforcing and complementary clusters that persist in the absence of external shocks or endogenous threats. Conditions of rough but durable equilibrium create the path-dependent trajectories that open or foreclose opportunities for long-run economic growth. The political economy of economic failure has thus re-emerged as a central preoccupation of economic historians of Latin America.

One of the most influential new works in this re-emerging field was the seminal essay by Stanley Engerman and Kenneth Sokoloff, first published in a volume of essays edited by Stephen Haber. ${ }^{37}$ To summarize brutally, Engerman and Sokoloff argued that factor endowments (the prevailing quantity, quality, and relative scarcities of land, labor, and capital) in Latin America in the colonial era gave rise to high levels of concentration of wealth, particularly land ownership, in contrast to the relatively egalitarian distribution of wealth in the northern colonies of British North America. Excessive concentration of wealth led to concentration of political power in the hands of narrow elites and thus to the creation of institutions that served elite interests and failed to protect the property rights of most citizens. In the mid-Atlantic and northern United States, by contrast, factor endowments favored family farms

35. For an early discussion, see, J. L. Gallup, Jeffrey Sachs, and A. Mellinger, "Geography and Economic Development," Annual World Bank Conference on Development Economics 1998 (Washington, D.C.: World Bank, 1999); for an application to Latin America, see Gerardo Esquivel, "Geografía y desarrollo económico en México" (Research Network Working Paper No. R-389 Inter-American Development Bank, Washington, D.C., April 2000). Geographic obstacles include absence of natural resources, difficult climatic conditions, distance from navigable waterways, and the like.

36. See, for example, Harold L. Cole, Lee E. Ohanian, Alvaro Riascos, and James A. Schmitz, Jr., "Latin America in the Rearview Mirror" (National Bureau of Economic Research Working Paper 11008 Cambridge, MA, December 2004), which argues that Latin America's poor growth performance is the result of barriers to both external and domestic competition such as protectionism and barriers to entry that privilege existing producers to a far greater extent than in other world regions.

37. Stanley Engerman and Kenneth Sokoloff, "Factor Endowments, Institutions, and Differential Growth Paths among New World Economies," in Haber, ed., How America Fell Behind, 260-304. 
rather than large estates. Greater equality in wealth distribution diffused political power more broadly and made it possible to create institutions that protected citizens and their property from arbitrary treatment by government. As a result, people in the United States made broad and continuous use of markets to exchange products and factors, while most Latin Americans, facing higher risks, did not.

The Engerman and Sokoloff thesis, while plausible, is almost certainly wrong. Though the institutional framework for colonial economic activity did not vary much across the Spanish American colonies, GDP per capita measured at the end of the colonial era diverged significantly. The gap between the richest and poorest Spanish colonies was almost as great as the gap between the richest and poorest regions in the world in the early nineteenth century. In 1800, for example, Cuba had a per capita income of $\$ 90$, compared to roughly $\$ 30$ for less-developed regions like Brazil and Peru, a ratio of three to one. ${ }^{38}$ Maddison's figures for the world economy in 1820 show a ratio of four to one between Western Europe and Africa, the richest and poorest regions respectively. ${ }^{39}$ Moreover, Spanish slave colonies like Cuba, where inequality must have been greatest, had the highest per capita GDP at that time. Most of the Spanish colonies were not slave colonies and, however rich or poor, there is no solid evidence to suggest unusually high levels of concentration of landownership. Unlike Western Europe, Latin America's colonial elites did not monopolize land ownership. Throughout Mesoamerica and the Andes, indigenous villages and villagers occupied most of the arable lands; European estates clustered in the commercially more profitable areas near cities and towns and along major trade routes but left vast areas of the landscape in indigenous hands. ${ }^{40}$ Even in the frontier and peripheral areas of the Argentine interior, where huge estates existed on paper, the value of the land was minimal and contributed little to concentrating wealth; the real source of wealth, the cattle, ran wild and belonged to no one until long after independence. Thus, landownership (and wealth more generally) was not more concentrated in Latin America than in the thirteen British colonies (or industrializing Britain itself). Moreover, as near as one can tell, inequality was positively correlated with GDP per capita, both within and between the Spanish colonies in the Americas, the case in point being the Caribbean slave colonies, which were enormously productive by any measure of output value. Since the Engerman and Sokoloff model posited a straightforward linear path dependence between an initially high concentration of landownership

38. Coatsworth, "Economic and Institutional Trajectories," 29.

39. Maddison, The World Economy, 262.

40. The contrast here is to Western Europe where powerful aristocracies excluded most peasants from owning arable land, even in areas where serfdom had never developed. 
in the colonial era, bad institutions, and relative backwardness, it can safely be discarded on empirical grounds.

The origins of the colonial property rights regime, along with slavery, caste systems, and most other economically relevant institutions cannot be found in New World factor endowments but in Old World policies and practices, adapted as needed to New World conditions. It was not New World factor endowments but Old World conquest and enslavement of ethnically distinct populations that made for "bad" institutions. But even if the fundamental institutions that defined economic organization in Latin America were Iberian in origin, it is still possible that colonial elites dominated the adaptive process and shaped them to suit their own interests. This did occur, it is true, but only within limits imposed by the colonial regime itself. For example, colonial elites in Spanish America could not enslave the indigenous population (after the 1540s). Moreover, the Crown also made sure that the indigenous population did not depend on the Creole settler elites for access to land and insisted that the royal courts protect indigenous lands from usurpation by local magnates. Colonial elites could not dominate colony-wide governments, repeal taxes and regulations on trade, abolish crown monopolies, or make war or peace. Colonial elites were first of all colonial, that is, relatively weak in comparison to European landowning aristocracies, so even if wealth had been highly concentrated, the Creole elites of Spanish America could not have remade the institutions that governed economic life just as they pleased. ${ }^{41}$

The concentration of wealth and elite institutional power that Engerman and Sokoloff attributed to colonial factor endowments did, in fact, arise in Latin America but much later, for different reasons, and with contrary results. They marked the onset of modernization in Latin America at the end of the nineteenth and beginning of the twentieth century. What Engerman and Sokoloff saw as obstacles to economic growth-elite power and economic inequality-actually facilitated the region's transition to sustained, if unstable, economic growth for most of the twentieth century. This rupture with the past took decades to achieve. Creole elites had to settle their internal feuds, mobilize resources to suppress indigenous peasants and other competitors for political power, undertake far-reaching legislative changes (from abolishing archaic forms of property holding to writing new commercial codes), and attract foreign capital to finance infrastructure and export production. The result was not stagnation, but growth.

How did Latin America achieve growth, saddled with what Engerman and Sokoloff condemned as obstacles to broad-based participation in

41. John H. Coatsworth and Gabriel Tortella Casares, "Institutions and Long-Run Economic Performance in Mexico and Spain, 1800-2000" (Working Papers on Latin America, Paper No. 02/03-1 David Rockefeller Center for Latin American Studies, Harvard University, 2002). 
the market? This issue was tackled in a recent work by Stephen Haber and his collaborators. ${ }^{42}$ "Crony capitalism" —or more awkwardly, "vertical political integration" (VPI), as Haber, Armando Razo, and Noel Maurer term it-is a system composed of "a rent-seeking coalition made up of asset holders, a government too weak to establish a despotic state, and a group that receives rents in exchange for enforcing the contract between the asset holders and the government." ${ }^{\prime 3}$ Rather than "limited government" with effective institutional constraints on governmental predation, which would have protected and served all citizens, the best Mexico could do after a half century of war and instability, was the Porfirian system of institutionalized cronyism that produced economic growth by guaranteeing protection to a small elite of politically connected bankers, industrialists, and foreign companies. The 1910 revolution fractured the Porfirian system and then virtually destroyed it in the chaotic period of civil warfare (1914-17), but even before the fighting had ended new deals were being cut.

The VPI model proposed by Haber, Razo, and Maurer provides a useful framework for addressing a major issue in Latin America's economic historiography, that is, how to account for the region's respectable rates of economic growth in the twentieth century, despite its persistent political instability. Extending this analytical framework to the rest of Latin America would help to refine and deepen our understanding of the region's modern political economy. The model is best at illuminating relationships that turn self-interested deal making into the kind of credible commitments against expropriation (in its many forms) that persuade capitalists to make investments. It is less successful, however, in approaching the macroeconomic issues that confront VPI governments with long time horizons. In the Mexican case, for example, Haber et al. treat the creation of Banamex in the 1880s as a case of insider deal making in which the Mexican government got a stream of revenue from the bank in exchange for privileges that could not be revoked without damaging the government itself. This is true as far as it goes, but as Haber et al. recognize, the Díaz government was also playing for higher stakes, seeking to use the banks as part of a strategy to achieve a coherent set of monetary, fiscal, and development objectives. ${ }^{44}$

42. Stephen Haber, Armando Rozo, and Noel Maurer, The Politics of Property Rights: Political Instability, Credible Commitments, and Economic Growth in Mexico, 1876-1929 (Cambridge, UK: Cambridge University Press, 2003).

43. Ibid., 29. In the authors' conception, VPI is the institutionalized version of crony capitalism.

44. On the Porfirian regime's strategy to use the new bank in the service of larger policy goals, see Thomas Passananti, "Managing Finance and Financiers: The Politics of Debt, Banking and Money in Porfirian Mexico" (Unpub. Ph.D. dissertation, University of Chicago, 2001). 
VPI governments were not merely predatory, as the model assumes, but at times farsighted. By the 1930s, many of these regimes even proved flexible enough to take a temporarily populist turn.

It would be a mistake, however, to reject the hypothesis of a significant link between colonial developments and modern economic performance. Indeed, the connection between the Iberian colonial regimes and economic backwardness has held a prominent place in writing about Latin America since before independence. This conventional idea received a decidedly unconventional boost recently in a series of papers by Daron Acemoglu, Simon Johnson, and James A. Robinson, the first of which, entitled "The Colonial Origins of Comparative Development: An Empirical Investigation," appeared in the American Economic Review in $2001 .{ }^{45}$ Acemoglu, Johnson, and Robinson showed that colonial areas with high death rates (mainly from tropical diseases) attracted fewer European settlers and those that did stay served mainly as colonial administrators and exploiters of local or imported slave populations. These areas tend to have less-productive modern economies, while colonies that attracted high proportions of European settlers tended to do better over the long run. The authors attributed the modern income gap between the two sets of colonies, like Engerman and Sokoloff, to differences in institutions. Colonies ruled by narrow foreign elites were saddled with institutions that did not protect the property rights of ordinary citizens; colonies with predominantly European populations ended up with good institutions. In contrast to Engerman and Sokoloff, who argued that inequality in wealth determined institutional development, Acemoglu, Robinson, and Johnson argued for the primacy of inequalities in legal status and political rights, determined not by factor endowments but by the structure of colonial rule. A later paper by the same authors documented what they called "The Reversal of Fortune."46 Areas of the globe that were the most urban and advanced before European colonization (such as Central Mexico and the Peruvian highlands), they argue, fell furthest behind after conquest. In this case, the causal mechanism is similar-the presence of dense populations of indigenous people whom the colonial rulers subjugated and exploited. On this reading, the key source of the institutional deficiencies that have inhibited growth and development in the twentieth century can be found not in factor endowments per se but in the political economy of conquest and enslavement.

45. American Economic Review, 91, no. 5. (December 2001): 1369-405.

46. Acemoglu, Johnson, and Robinson, "Reversal of Fortune: Geography and Institutions in the Making of the Modern World Income Distribution," Quarterly Journal of Economics, 117 (November 2002): 1231-94. 
This recent work has raised, or perhaps merely raised anew, two major questions addressed by the structuralist and dependentista historians and economists two generations ago. The first question is whether the evidence available will permit a systematic investigation of the precise mechanisms that link colonial society, politics, and institutions to economic performance during and beyond the colonial era. The second question is how the new political economic equilibrium that emerged in the late nineteenth century (Haber's "crony" capitalism or vertical political integration) may have been shaped by the colonial legacy it finally replaced. Contrary to Engerman and Sokoloff, however, neither can be answered by looking at colonial land holding. Political and economic power in Latin America since pre-Hispanic times has accumulated powerfully only when urban rulers have managed to dominate the countryside.

The late-nineteenth-century political economic rupture came after prolonged turmoil and struggle in which the balance shifted decisively in favor of economic elites, but this shift could only have occurred in an era of export-led globalization. Haber and his collaborators demonstrated this connection clearly in attributing Díaz's success in creating his pioneering VPI regime in Mexico to "an advantage that was not available to any previous Mexican president: the ability to integrate with the U.S. economy." ${ }^{\prime 7}$ This hypothesis will strike some readers as excessively dependentista, but it is almost certainly right. Without railroads to make Mexico's resources economically accessible, along with the foreign (and domestic) investment their construction provoked, the Díaz regime would have failed. Throughout Latin America in the late nineteenth and early twentieth centuries, VPI regimes succeeded where predecessors had failed because of globalization. Thus, I suspect as these questions continue to be explored, students and scholars will soon find themselves looking for additional insights in some of the ancient structuralist and dependentista texts many stopped reading a decade or two ago.

A good diagnosis is at least as important as finding the right medicine. As Latin Americans (and Latin Americanists) search for a way out of the economic stagnation that the region has experienced over the past quarter century, critiques of the Washington Consensus and globalization will surely intensify. To the extent that such critiques succeed in persuading voters that the region would be better off with less external trade and investment, less imported technology, higher inflation, and more regulation and state ownership, they should probably be seen as costly distractions at best. 


\section{Latin American Research Review}

On the other hand, perhaps the region is witnessing not so much the collapse of the Washington Consensus as the slow-motion disintegration of the political economy that emerged at the end of the nineteenth century. This system of weak institutions (even with big and occasionally repressive governments) and concentrated wealth generated sustained economic growth and gradual improvements in living standards for most of the twentieth century. It proved flexible enough to incorporate statist or populist variants, but has suffered in recent years as neoliberal policies imposed initially by external conditions and interests have reduced the capacity of governments to sustain the privileged position of many protected sectors and groups. Even so, it might have adjusted and survived had it not been for the transition to democratic rule throughout much of the region.

The "economic system in which property rights are specified and enforced as private goods ${ }^{\prime \prime 8}$ now appears exhausted. As Haber, Razo, and Maurer put it, this system "requires the creation of rent-seeking coalitions, is economically inefficient, has negative consequences for the distribution of income, implies political authoritarianism, and requires that government be an inefficient provider of public services." ${ }^{49}$ It may be that Latin America is on the cusp of a new rupture with the past, one that could eventually lead to more equal societies, stimulate a broader and more popular capitalism (à la Engerman and Sokoloff), and serve to create a more efficient, effective, and transparent state apparatus. Some countries seem already well launched in this direction. In many, the winds of change are pushing ships of state to the left, a tack that carries great promise but also grave risks. New systems of political and economic power seldom emerge from straight lines on a legible map, so scholars as well as policy makers and economic actors may find it convenient to not only follow developments with a healthy skepticism, but also to raise their tolerance for political, social, and even economic experimentation in coming years. 